ORIGINAL ARTICLE

Hatice Sema Başak ${ }^{1}$

Özkan Doğan ${ }^{1}$

Okay Başak ${ }^{2}$

Corresponding Author:

Okay Başak

Adnan Menderes University

Hospital Family Medicine Clinic,

Aydin, Turkey

Tel: +90 2564441256/2946

E-mail:okaybasak@yahoo.com

Received: 14.11.2018

Acceptance: 03.02.2019

DOI: $10.18521 / \mathrm{ktd} .482773$

Konuralp Medical Journal

e-ISSN1309-3878

konuralptipdergi@duzce.edu.tr

konuralptipdergisi@gmail.com

www.konuralptipdergi.duzce.edu.tr

\section{The Power of Diagnostic Tests for Benign Paroxysmal Positional Vertigo: A Syndromic Approach ABSTRACT}

Objective: To determine diagnostic power of the symptoms and findings of patients with complaints of dizziness/balance disorder and to identify the syndromic diagnostic components for the benign paroxysmal positional vertigo (BPPV).

Methods: A retrospective methodological study of 147 adult patients with dizziness/balance disorder visiting the Otorhinolaryngology Clinic between January and December 2014 was conducted. The symptoms, signs and laboratory test results of the patients in BPPV and non-BPPV groups were compared and analyzed through sensitivity, specificity, predictive values, likelihood ratios, post-test odds and probabilities, logistic regression analysis and ROC curve. The criterion indices having high post-test probability values were determined.

Results: The most common three diagnoses were psychogenic vertigo (34.0\%), peripheral vertigo of unknown origin (22.4\%), and BPPV (16.3\%). Five complaints and findings were found to have statistically significant diagnostic power: characteristic dizziness complaint, dizziness attacks lasting less than two minutes, dizziness being present for less than one week, supine roll and Dix-Hallpike test positivity. The post-test probability increased to $95.4 \%$ in patients with attacks lasting less than two minutes and dizziness lasting less than one week, when the Dix-Hallpike test was positive (triple-index positivity). According to the logistic regression model, positive result of the Dix-Hallpike test increased the probability of BPPV by 65.6 times. Accuracy of the model was $92.5 \%$, with the area under the ROC curve of 0.891.

Conclusions: Our study results have provided evidence basis for diagnostic power of the Dix Hallpike test and, to a lesser extent, of the supine roll test.

Keywords: Benign Paroxysmal Positional Vertigo, Diagnosis, Syndromic Approach.

\section{Benign Paroksismal Pozisyonel Vertigo İçin Tanısal Testlerin Gücü: Sendromik Yaklaşım \\ ÖZET}

Amaç: Bu çalışmanın amacı baş dönmesi/denge bozukluğu yakınması olan hastaların semptom ve bulgularının benign paroksismal pozisyonel vertigo (BPPV) için tanısal gücünü belirlemek ve sendromik tanısal bileşenleri tanımlamaktır.

Gereç ve Yöntem: Ocak-Aralık 2014 tarihleri arasında kulak burun boğaz polikliniğine başvuran ve baş dönmesi/denge bozukluğu olan 147 yetişkin hastayla retrospektif metodolojik bir çalışma yapıldı. BPPV olan ve olmayan hastaların semptom, belirti ve laboratuvar test sonuçları karşılaş̧ırıldı ve duyarlılık, seçicilik, kestirim değerleri, olasılık oranları, test sonrası odds ve olasılıkları, lojistik regresyon analizi ve ROC eğrisi aracılığıyla değerlendirildi. Yüksek test sonrası olasılık değerleri olan kriter indeksleri belirlendi.

Bulgular: En sık konulan üç tanı psikojenik vertigo $(\% 34,0)$, kökeni bilinmeyen periferik vertigo $(\% 22,4)$ ve BPPV $(\% 16,3)$ idi. Beş yakınmma ve bulgunun istatistiksel olarak anlamlı tanısal gücü olduğu saptandı: Karakteristik baş dönmesi yakınması, iki dakikadan daha kısa süren baş dönmesi atakları, bir haftadan daha kısa süredir var olan baş dönmesi, supine roll ve Dix-Hallpike test pozitifliği. Atakları iki dakikadan kısa süren ve bir haftadan daha kısa süredir baş dönmesi olan hastalarda Dix-Hallpike testi pozitif çıktığında test sonrası olasılık \%95,4'e çıkmaktaydı (üçlü-indeks pozitifliği). Lojistik regresyon modeline göre, pozitif Dix-Hallpike test sonucu BPPV olasılığını 65,6 kat artırmaktaydı. Modelin doğruluğu, 0,891'lik ROC eğrisi altında kalan alan değeriyle $\% 92,5$ olarak hesaplandi.

Sonuç: Çalışma sonuçlarımız supine roll testi için daha düşük olmak üzere Dix-Hallpike testinin tanısal gücü için kanıt temeli sağlamıştır.

Anahtar Kelimeler: Benign Paroksismal Pozisyonel Vertigo, Tanı, Sendromik Yaklaşım 


\section{INTRODUCTION}

Currently, diagnosing a patient with dizziness and balance disorder involves difficulties. Benign paroxysmal positional vertigo (BPPV) is one of the most commonly seen clinical conditions in these patients and the evidence regarding diagnosis and treatment of BPPV are insufficient (1). It is stated that the guidelines for diagnosis and treatment of dizziness/balance disorder do not contain data that are crucial for medical decisionmaking, such as sensitivity, specificity, and likelihood ratio and that consensus recommendations are mostly available in these guidelines (2).

The syndromic approach is making diagnosis by using various specific components of medical history and physical examination and has first been proposed for the diagnosis and treatment of genital system infections by the World Health Organization $(3,4)$. In a study conducted in Turkey, syndromic diagnostic components have been determined for the diagnosis of vulvovaginal candidiasis (5). It has also been suggested that data for as many clinical conditions as possible that can be used especially in primary care should be obtained and family physicians should make a habit of questioning the odds and predictive values of more diagnostic tests $(3,4,6)$.

Studies related to determining the diagnostic power of symptoms and findings presented by patients and related to the syndromic approach are limited. The aim of this study is to determine to what extent symptoms and findings obtained in medical history, physical examination and laboratory investigations of patients with a complaint of dizziness/balance disorder contribute to the diagnosis of BPPV, and therefore, their diagnostic powers. From here, we aim to identify syndromic diagnostic components for the diagnosis of BPPV.

\section{MATERIAL AND METHODS}

Study design: This study had methodological design. Patient information was retrospectively obtained from the "Vertigo Polyclinic Patient Evaluation Forms" of the patients which contained demographic data, symptoms, signs, attack characteristics, ear nose and throat (ENT) and balance examination findings, audiological and laboratory test results in addition to videoelectronystagmography (VNG).

Study subjects: In this study, 147 adult patients with a complaint of dizziness or imbalance, visiting Adnan Menderes University Hospital Otorhinolaryngology Clinic were consecutively recruited between January and December 2014.

Test methods: "Recurrent and severe rotational sensation of the patient or the surrounding, manifested following sudden head movement" was regarded as characteristic dizziness (1). All other expressions were evaluated as balance disorder. Preliminary diagnosis of BPPV was made by using positional tests and taking the data obtained from medical history and physical examination into consideration. Preliminary diagnoses of posterior canal BPPV (PC-BPPV), lateral canal BPPV (LC-BPPV) and anterior canal BPPV (AC-BPPV) were made using positional tests (Dix-Hallpike maneuver, supine roll test) in accordance with the descriptions in the BPPV Clinical Practice Guideline, American Academy of Otolaryngology - Head and Neck Surgery Foundation $2008(1,7)$. The definitive diagnosis of BPPV was made by observing characteristic nystagmus during the positional tests in VNG and VNG was accepted as the gold standard (8). In cases that positional tests were normal in VNG, other diagnoses (Meniere's disease, vestibular neuritis, vertiginous migraine, central vertigo, psychogenic vertigo and peripheral vertigo of unknown origin) were also made in accordance with the related descriptions in the above mentioned guideline (1). Patients who described no complaint of dizziness/balance disorder as the chief complaint, those who did not adhere to recommendations for VNG test, those who were under the age of eighteen, and those who had a perforation of the tympanic membrane were excluded from the study.

Statistical analysis: The patients were divided into two groups as BPPV and non-BPPV according to the definitive diagnoses. The Statistical Package for Social Sciences version 21 was used for statistical analyses. Results with the $\mathrm{p}<0.05$ value were regarded as statistically significant. Descriptive statistics, KolmogorovSmirnov test, independent sample t-test, MannWhitney U test, Chi-square test, Fischer test were used for statistical evaluation of the study data. Sensitivity, specificity, predictive values, likelihood ratios (LR), post-test odds and probabilities for the variables having significant results in the univariate analysis were calculated. The variables with a positive LR in the range of between 1.2 and 1.9 were considered as low, between 2.0 and 4.9 as moderate, and above 5.0 as high increase in the probability of disease. Post-test probability values were calculated for different variables using the chain likelihood ratio method and criterion indices having high post-test probability values were determined (9). Positive LR was determined by using the formula "sensitivity of the test/1specificity of the test". Post-test odds was obtained by multiplying positive LR with pre-test odds. Pretest odds was calculated as 'pre-test probability/1pre-test probability'. Post-test odds was converted to probability by dividing it to 1 plus itself (6). Multiple logistic regression analysis was performed to determine the effects of independent variables on the dependent variable. Receiver operating characteristic (ROC) curve was drawn according to the probability cut-off values obtained in regression 
analysis and AUC (area under ROC curve) was calculated.

Ethical approval for the study was obtained from Adnan Menderes University Medical Faculty, Ethics Committee for Non-interventional Research (Protocol no:2014/510, 13.03.2014).

\section{RESULTS}

The mean age of 147 patients included in the study was $48.6 \pm 15.1$, and the female/male distribution was 75/72. The most common three diagnoses were psychogenic vertigo (34.0\%), peripheral vertigo of unknown origin $(22.4 \%)$, and BPPV (16.3\%). All diagnoses are shown in Table 1.

Table 1. The diagnoses of all patients included in the study, $\mathrm{n}=147$

\begin{tabular}{lcc}
\hline Diagnoses & Number & \% \\
\hline Psychogenic vertigo & 50 & 34.0 \\
Peripheral vertigo with unknown origin & 33 & 22.4 \\
Benign Paroxysmal Positional Vertigo & 24 & 16.3 \\
Central vertigo & 16 & 10.8 \\
Meniere disease & 14 & 9.5 \\
Vestibular neuritis & 6 & 4.0 \\
Vertiginous migraine & 4 & 2.7 \\
\hline
\end{tabular}

All preliminary diagnoses of BPPV made by the ENT clinician were confirmed following VNG; there were no other patients diagnosed through VNG but had no preliminary diagnosis of BPPV. In 24 patients diagnosed with BPPV, the most common type was PC-BPPV with $79.1 \%(n=19)$, followed by LC-BPPV $(16.6 \% ; n=4)$ and AC$\operatorname{BPPV}(4.1 \% ; \mathrm{n}=1)$.

The patients with and without BPPV did not show any differences regarding age and gender $(p>0.05)$. The main complaint of characteristic dizziness, the onset of complaints within the last week, the dizziness lasting less than 2 minutes, and positive results for the Dix-Hallpike maneuver and the supine roll test were significantly higher in the group with BPPV when compared to the group without BPPV $(\mathrm{p}<0.05)$. No significant differences were found between two groups regarding other symptoms, attack features, triggering conditions, additional disorders, use of any drugs, and ENT examination and other laboratory test results $(p>0.05)$. The diagnostic test results that are found to be statistically significant comparing to the definitive diagnosis of BPPV are shown in Table 2.

Table 2. The diagnostic test (history and physical examination) features that were found to be statistically significant comparing to the definitive diagnosis of BPPV

\begin{tabular}{|c|c|c|c|c|c|c|c|}
\hline \multirow{2}{*}{\multicolumn{2}{|c|}{ Complaints and findings }} & \multicolumn{3}{|c|}{ Diagnosis of BPPV } & \multirow{2}{*}{$\begin{array}{c}\text { Sensitivity } \\
\text { and } \\
\text { specificity }\end{array}$} & \multirow{2}{*}{$\begin{array}{l}\text { Predictive } \\
\text { values }\end{array}$} & \multirow[b]{2}{*}{ Statistics } \\
\hline & & Yes, n & No, n & Total, n & & & \\
\hline \multirow{3}{*}{$\begin{array}{l}\text { Characteristic } \\
\text { dizziness }\end{array}$} & Present & 24 & 105 & 129 & \multirow{3}{*}{$\begin{array}{l}\text { Sen: } \% 100 \\
\text { Spe: } \% 14.6\end{array}$} & PPV: & \multirow{3}{*}{$\begin{array}{l}\chi^{2}=4.002 \\
p=0.045\end{array}$} \\
\hline & Absent & 0 & 18 & 18 & & $\% 18.6$ & \\
\hline & Total & 24 & 123 & 147 & & NPV: $\% 100$ & \\
\hline \multirow{3}{*}{$\begin{array}{l}\text { The supine roll } \\
\text { test* }\end{array}$} & + & 3 & 0 & 3 & \multirow{3}{*}{$\begin{array}{l}\text { Sen: } \% 12.5 \\
\text { Spe: } \% 100\end{array}$} & \multirow{3}{*}{$\begin{array}{l}\text { PPV: } \% 100 \\
\text { NPV:\%85.4 }\end{array}$} & \multirow{3}{*}{$\begin{array}{c}\chi^{2}=15.695 \\
p=0.004\end{array}$} \\
\hline & - & 21 & 123 & 144 & & & \\
\hline & Total & 24 & 123 & 147 & & & \\
\hline \multirow{3}{*}{$\begin{array}{l}\text { The Dix- } \\
\text { Hallpike test }\end{array}$} & + & 12 & 2 & 14 & \multirow{3}{*}{$\begin{array}{l}\text { Sen: } \% 50.0 \\
\text { Spe: } \% 98.4\end{array}$} & \multirow{3}{*}{$\begin{array}{l}\text { PPV:\%85.7 } \\
\text { NPV:\%91.0 }\end{array}$} & \multirow{3}{*}{$\begin{array}{c}\chi^{2}=54.535 \\
p<0.001\end{array}$} \\
\hline & - & 12 & 121 & 133 & & & \\
\hline & Total & 24 & 123 & 147 & & & \\
\hline \multirow{3}{*}{$\begin{array}{l}\text { Complaint } \\
\text { duration }\end{array}$} & $\leq 1 \mathrm{wk}$ & 9 & 23 & 32 & \multirow{3}{*}{$\begin{array}{l}\text { Sen: } \% 37.5 \\
\text { Spe: } \% 81.3\end{array}$} & \multirow{3}{*}{$\begin{array}{l}\text { PPV:\%28.1 } \\
\text { NPV:\%87.1 }\end{array}$} & \multirow{3}{*}{$\begin{aligned} \chi^{2} & =4.168 \\
p & =0.041\end{aligned}$} \\
\hline & $>1 \mathrm{wk}$ & 15 & 100 & 115 & & & \\
\hline & Total & 24 & 123 & 147 & & & \\
\hline \multirow{3}{*}{ Attack duration } & $\leq 2 \min$ & 12 & 36 & 48 & \multirow{3}{*}{$\begin{array}{l}\text { Sen: } \% 50.0 \\
\text { Spe: } \% 70.7\end{array}$} & \multirow{3}{*}{$\begin{array}{l}\text { PPV:\%25.0 } \\
\text { NPV:\%87.9 }\end{array}$} & \multirow{3}{*}{$\begin{aligned} \chi^{2} & =3.925 \\
\mathrm{p} & =0.048\end{aligned}$} \\
\hline & $>2 \min$ & 12 & 87 & 99 & & & \\
\hline & Total & 24 & 123 & 147 & & & \\
\hline
\end{tabular}

* Fisher's Exact test

BPPV: Benign Paroxysmal Positional Vertigo; Sen: Sensitivity; Spe: Specificity; PPV: Positive Predictive Value; NPV: Negative Predictive Value; wk: week; min: minute

Five complaints and findings were found to have statistically significant diagnostic power. Sensitivity of the characteristic dizziness complaint and specificity of the supine roll test for the diagnosis of BPPV were $100 \%$. Three criteria were identified for the diagnosis of BPPV, one weakly, one moderately, and one strongly positive. Dizziness attacks lasting less than two minutes increased the BPPV probability to $25.0 \%$, with dizziness being present for less than one week to $28.1 \%$, and positive Dix-Hallpike test result up to
$85.9 \%$. The post-test probability increased to $40.1 \%$ in patients with dizziness present for less than one week and attacks lasting less than two minutes (double-index positivity); to $91.2 \%$ in patients with attacks shorter than two minutes and positive DixHallpike test (double-index positivity); to $92.4 \%$ in patients with dizziness for a period less than one week and positive Dix-Hallpike test (double-index positivity), and to $95.4 \%$ in patients with attacks lasting less than two minutes and dizziness lasting less than one week, when the Dix-Hallpike test was 
positive (triple-index positivity). Pre-test and posttest diagnostic features of the significantly positive variables and criteria for the diagnosis of BPPV are shown in Table 3.

Table 3. The pre-test and post-test diagnostic features of the significantly positive variables and criteria for the diagnosis of benign paroxysmal positional vertigo

\begin{tabular}{|c|c|c|c|c|c|}
\hline $\begin{array}{l}\text { Variables and } \\
\text { indices }\end{array}$ & $\begin{array}{c}\text { Pre-test } \\
\text { probability }\end{array}$ & Pre-test odds & $\begin{array}{c}\text { + Likelihood } \\
\text { ratio }\end{array}$ & Post-test odds & $\begin{array}{c}\text { Post -test } \\
\text { probability }\end{array}$ \\
\hline Attack duration & 0.1632 & 0.1950 & 1.71 & 0.333 & 0.2501 \\
\hline $\begin{array}{l}\text { Complaints } \\
\text { duration }\end{array}$ & 0.1632 & 0.1950 & 2.01 & 0.390 & 0.2805 \\
\hline $\begin{array}{l}\text { Dix-Hallpike } \\
\text { test }\end{array}$ & 0.1632 & 0.1950 & 31.25 & 6.093 & 0.8590 \\
\hline 2-index* & 0.2501 & 0.3335 & 2.01 & 0.670 & 0.4012 \\
\hline 2-index** & 0.2501 & 0.3335 & 31.25 & 10.422 & 0.9124 \\
\hline 2-index $* * *$ & 0.2805 & 0.3898 & 31.25 & 12.181 & 0.9241 \\
\hline 3-index $* * * *$ & 0.4012 & 0.6700 & 31.25 & 20.938 & 0.9544 \\
\hline \multicolumn{6}{|c|}{$\begin{array}{l}\text { * Double-index positivity: Dizziness present for less than one week and attacks lasting less than } 2 \text { minutes } \\
\text { ** Double-index positivity: Attacks shorter than two minutes, when the Dix-Hallpike maneuver is positive } \\
\text { ** Double-index positivity: Dizziness for a period less than one week, when the Dix-Hallpike test is positive } \\
\text { *** Triple-index positivity: Attack lasting for less than two minutes and dizziness lasting for less than one } \\
\text { week, when the Dix Hallpike test is positive }\end{array}$} \\
\hline
\end{tabular}

Additionally, logistic regression analysis was performed to verify diagnostic contribution of five variables significantly positive for the diagnosis of BPPV. A model with one variable was constituted in logistic regression analysis (Table 4). According to this model, positive result of the DixHallpike test increased the probability of BPPV by 65.610 fold (95\% CI: 11.988-359.069; $\mathrm{p}=0.000$ ).
The ROC curve, drawn according to the probability estimates obtained through the regression analysis has been shown in Figure 1. With ROC analysis, accuracy rate of the one-variable model was $92.5 \%$, and area under the curve was found as 0.891 (0.813-0.969). The optimum sensitivity threshold was 0.833 (Figure 1).

Table 4. Logistic regression model with one variable, performed for determining the contributions of the independent variables to the diagnosis of BPPV

\begin{tabular}{lcccccc}
\hline \multicolumn{7}{l}{ Dependent variable: Presence of benign paroxysmal positional vertigo } \\
\hline $\begin{array}{l}\text { Independent variable } \\
\text { Dix-Hallpike test }\end{array}$ & Beta & SE & Wald & p & Odds ratio & 95\% CI \\
positive & 4.184 & 0.867 & 23.272 & 0.000 & 65.610 & $11.988-359.069$ \\
\hline Constant & -32.744 & 23646.528 & 0.000 & 0.999 & 0.000 & \\
\hline
\end{tabular}

BPPV: Benign paroxysmal positional vertigo; SE: Standard Error; CI: Confidence interval

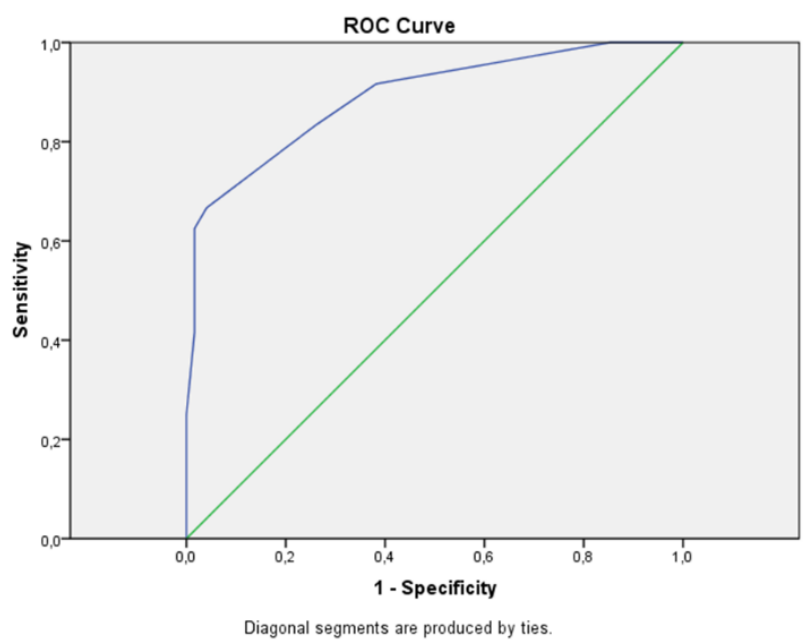

Figure 1. The ROC (Receiver Operating Characteristic) curve drawn according to the probability estimates obtained through logistic regression analysis 


\section{DISCUSSION}

The BPPV Clinical Practice Guideline published by American Academy of Otolaryngology-Head and Neck Surgery Foundation in 2008 emphasizes the importance of developing definitive and sufficient methods for the diagnosis (1). We think that our study results provide the evidence basis for the diagnostic value of some symptoms and signs in medical history and physical examination used by family physicians and ENT practitioners in BPPV diagnosis.

Laboratory facilities such as vestibular evoked myogenic potentials, VNG, and posturography, which can be used for evaluation of a patient with dizziness/balance disorder, are not available in most of the health centers. Performing these tests is time-consuming, and their interpretation needs experience $(1,8)$. Diagnostic criteria obtained by syndromic approach help us to make our clinical decision by separating the possibility of a disease (e.g., BPPV) into low, intermediate and high categories. The intermediate category includes doubtful conditions, and in this category, additional investigations may be required for verification of the diagnosis. In low and high categories, additional investigations will not be helpful for making a diagnosis (6).

The syndromic approach to the diagnosis of BPPV that we have developed has been shown in Figure 2. Sensitivity of the characteristic dizziness complaint regarding the diagnosis of BPPV is $100 \%$. Since there are no false negatives, we can be confident that the diagnosis is not BPPV in the absence of characteristic dizziness. So, starting with questioning the characteristic dizziness complaint in the diagnostic process for BPPV would be appropriate. However, due to the multitude of false positives, the presence of characteristic dizziness in a person is not diagnostic (18.6\% positive predictive value with $100 \%$ sensitivity and $14.6 \%$ specificity, at $16.3 \%$ prior probability).

Since there are no false positives, we can be confident that the diagnosis is BPPV when the supine roll test is positive in a patient with complaint of characteristic dizziness. However, the test is able to capture very few of the real BPPV patients. Due to the presence of false negatives, negative supine roll test is not detracting from BPPV diagnosis $(85.4 \%$ negative predictive value with $12.5 \%$ sensitivity, and $100 \%$ specificity, at $16.3 \%$ prior probability) and when the test is negative, other diagnostic tests should be continued for identifying the remaining BPPV cases. When the Dix-Hallpike test is not positive, particularly in a patient with a medical history of recurrent dizziness following head movements, performing the supine roll test is definitely recommended for the diagnosis of lateral canal BPPV (1). However, we suggest the supine roll test evaluation be made prior to the Dix-Hallpike test during the diagnostic process. When the test turns out to be positive, we are able to diagnose lateral canal BPPV. When the result is negative, we should continue our investigation towards diagnosing other BPPV types with the Dix-Hallpike test. This approach could be a way of solving the problem of "canal switch" being thought to occur following performance of the repositioning maneuvers for an initial diagnosis of posterior canal BPPV (10).

Our study results have revealed three criteria with diagnostic power in patients with a complaint of characteristic dizziness, but having negative supine roll test result. We suggest performing the Dix-Hallpike test as the third step for these patients. The positive result of this test leads to a serious increase in the probability of BPPV diagnosis. When an attack duration less than 2-minute and dizziness present less than 2-week are added to the Dix-Hallpike test positivity, the likelihood of BPPV diagnosis increases more, although limited. When all of these three tests are positive (triple-index positivity), the probability of BPPV diagnosis nearly approaches $100 \%$ (Table 3 ). As seen in the diagram, we can make the diagnosis of BPPV in all situations that the Dix-Hallpike test is positive, with no need for further tests and investigations like VNG (Figure 2). Hanley and O'Dowd have reported a positive predictive value of $83 \%$ and a negative predictive value of $52 \%$ for the Dix Hallpike test in diagnosing BPPV (11). The authors have suggested that when the test is negative the diagnosis should not be excluded and the test should be repeated in a new encounter to confirm the diagnosis and avoid false negative results. Predictive values are, of course, one of the criteria showing the power of diagnostic tests. However, for this, the clinician should foresee the prior risk before the test in every patient. The likelihood ratios, calculated through sensitivity and selectivity, are not affected by prior probability. The clinician is able to use the predetermined likelihood ratios in every situation.

The power of the Dix-Hallpike test in diagnosing BPPV has been supported by logistic regression and ROC analyses. While the limited powers of the supine roll test and other three history indexes for diagnosing BPPV, defined with the likelihood ratios, cannot be shown in regression analysis, the Dix-Hallpike test itself has constituted a powerful model. It can be said that the results obtained for the Dix-Hallpike test, the values of the odds ratio obtained by logistic regression analysis and AUC are consistent.

When Dix-Hallpike test is negative, the likelihood of BPPV diagnosis is reduced. In cases that dizziness has been present for less than two weeks, with attacks lasting less than two minutes or both, the likelihood of BPPV diagnosis is over $25 \%$ but remains below $65 \%$. In this case, further 


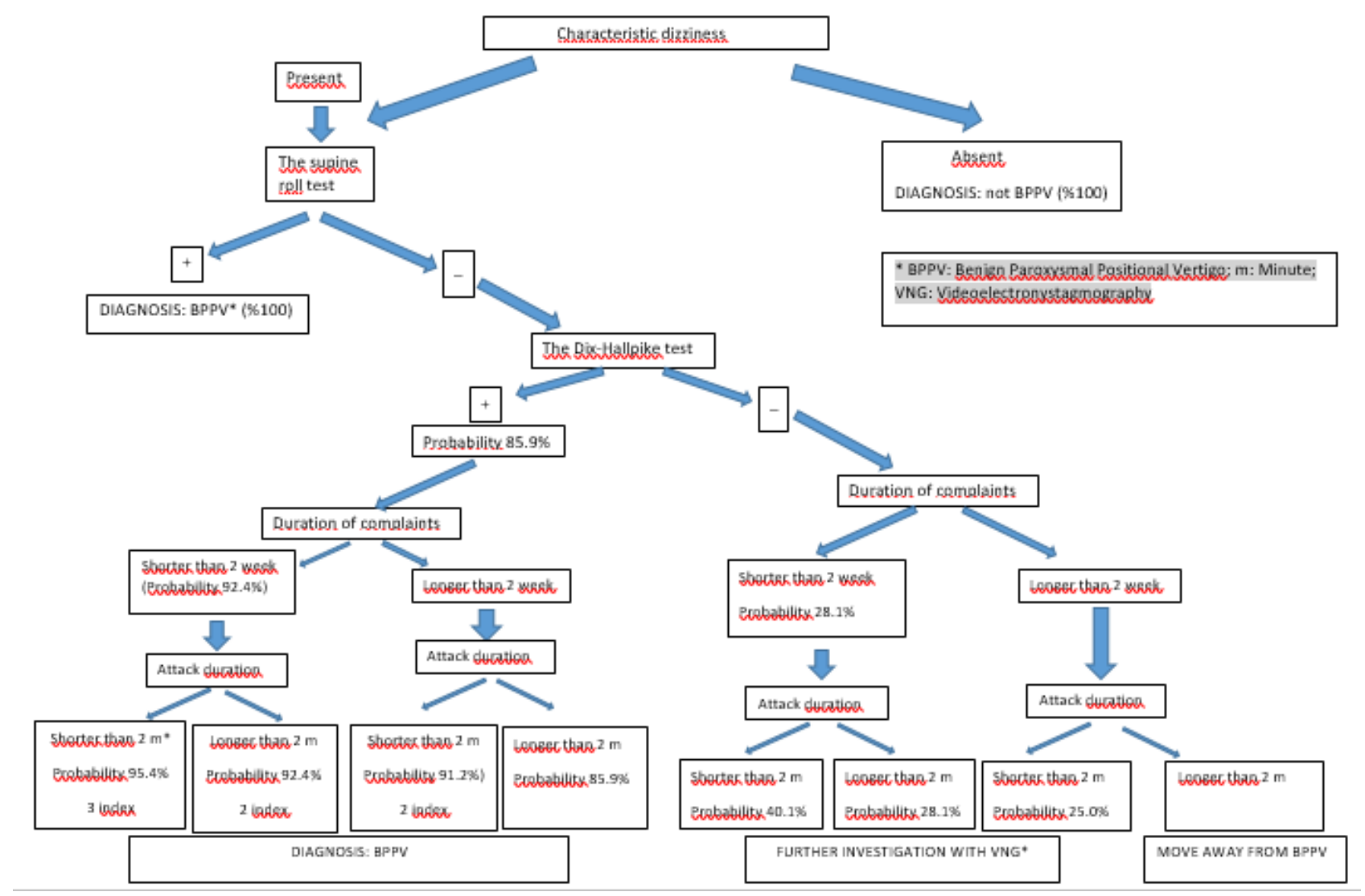

Figure 2. Syndromic approach to the diagnosis of Benign Paroxysmal Positional Vertigo

investigation with $\mathrm{VNG}$ will be required for the diagnosis of BPPV (Figure 2).

On the other hand, in the presence of the characteristic dizziness, but in the absence of the other four history and physical examination findings the diagnostic powers of which we have determined, the appropriate approach will be to move away from BPPV diagnosis without making further investigations, towards other diagnostic probabilities (Figure 2).

As a conclusion, our study results have provided evidence basis for diagnostic power of the Dix-Hallpike test, which ENT practitioners and family physicians have been using for diagnosing BPPV, based on their experiences and intuitively, and to a lesser extent, for diagnostic power of the supine roll test.

The Limitations of the Study: The study has been conducted in a university hospital facility, although its results are mostly applicable for family physicians and ENT practitioners working at primary and secondary care level of healthcare system. However, because the study design is methodological we think that its results are generalizable to all levels of healthcare system. There may be some troubles in the analysis of study results in terms of meeting the assumptions of the applied tests due to the small number of data in some cells of the crosstabs. Although statistically significant, sensitivities of some diagnostic tests are found to be low, whereas the sensitivities or specificities of some others are $100 \%$. However, $100 \%$ specificity of the supine roll test can be explained by the fact that this test is specific for the lateral canal BPPV. From this point, the demonstration of the supine roll test to be a gold standard for the LC-BPPV may be targeted in further studies that will be performed with larger groups of patients and the LC-BPPV taken as the dependent variable.

\section{REFERENCES}

1. Bhattacharyya N, Baugh RF, Orvidas L, et al. Clinical practice guideline: Benign paroxysmal positional vertigo. Otolaryngol Head Neck Surgery. 2008;139:47-81.

2. Kerber KA, Fendrick AM. The evidence base for the Evaluation and Management of Dizziness. NIH Public Access. J Eval Clin Pract. 2010;16: 86-91.

3. Pettifor A, Walls J, Wilkins V, et al. How effective is syndromic management of STDs. A review of current studies. Sexually Transmitted Diseases. 2000;27:371-85.

4. Ranjan R, Sharma AK, Mehta G. Evaluation of WHO diagnostic algorithm for reproductive tract infections among married women. Indian Journal of Community Medicine. 2003;28(2):81-4 
5. Bengi AM, Mevsim V, Yıldırım E. [Syndromic approach to vulvovaginal candidiasis.] Türk Aile Hek Derg. 2014; 18: 175-88.

6. Freeman TR. In McWhinney's Textbook of Family Medicine. 4th edition. New York: Oxford University Press; 2016. 203-264 pp.

7. Crane BT, Minor LB. Peripheral Vestibular Disorders. In: Cummings Otolaryngology Head Neck Surgery. Eds: Flint PW, Haughey BH, Lund VJ, Niparko JK, Robbins T, Thomas JR, Lesperance MM. 6th edition. Elsevier; 2015: 2548-2566 pp.

8. Al Saif A, Alsenany S. Sensitivity and specificity of the amer dizziness diagnostic scale (adds) for patients with vestibular disorders. J Phys Ther Sci. 2015;27: 91-6.

9. Sackett DL, Strauss ES, Richardson SW, et al. (eds). Evidence-Based Medicine: How to Practice and Teach EBM. Edinburg: Churchill Livingstone Elsevier; 2000;79-114 pp.

10. White JA, Coale KD, Catalano PJ, et al. Diagnosis and management of lateral semi-circular canal benign paroxysmal positional vertigo. Otolaryngol Head Neck Surg. 2005;133:278-84.

11. Hanley K, O' Dowd T. Symptoms of vertigo in general practice: a prospective study of diagnosis. Br J Gen Pract. 2002;52:809-12 